\title{
Management of Femoral Fractures in Aging Adult Polio Population: A Retrospective Review of 13 Cases
}

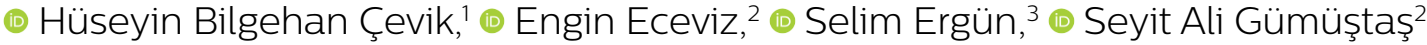

\begin{abstract}
'Department of Orthopedics and Traumatology, Dıșkapı Yıldırım Beyazıt Training and Research Hospital, Ankara, Turkey ${ }^{2}$ Department of Orthopedics and Traumatology, University of Health Sciences, Kartal Dr. Lütfi Kırdar Training and Research Hospital, İstanbul, Turkey

${ }^{3}$ Department of Orthopedics and Traumatology, Acıbadem University Faculty of Medicine, İstanbul, Turkey
\end{abstract}

Submitted: 08.07.2019 Accepted: 21.08.2019

Correspondence: Hüseyin Bilgehan Çevik Dışkapı Yıldırım Beyazıt Eğitim ve Araştırma Hastanesi, Ortopedi ve Travmatoloji Kliniği, Ankara, Turkey E-mail: bilgehancevik@gmail.com

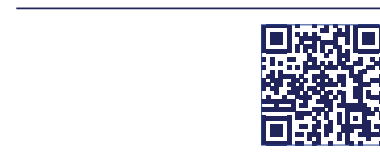

Keywords: Femur fracture; disuse osteoporosis; polio.

This work is licensed under a Creative Commons
Attribution-NonCommercial 4.0 International License.

\begin{abstract}
Objective: Polio survivors have common sequelae of lower extremity paralysis characterized by flaccid muscle tone, limited ambulation, asymmetric involvement, retarded growth, and disuse osteoporosis. Such patients at risk of disuse osteoporosis are also at risk of sustaining osteoporotic fractures. This study aims to evaluate the effectiveness of extramedullary internal fixation devices in achieving better results in osteoporotic poliorelated femoral fractures.
\end{abstract}

Methods: Retrospective evaluation was made of a total of 13 adult polio patients treated with extramedullary internal fixation devices for unilateral proximal and diaphyseal femoral fractures. The functional status of all patients was evaluated with the Vignos grade of disability.

Results: All patients (mean age 62 years; range 47-88 years) were treated with extramedullary internal fixation devices (locked plate in eight diaphyseal fractures; dynamic condylar screw (DCS) and plate in three, and dynamic hip screw (DHS) and plate in two proximal femoral fractures). The mean follow-up period was 48.6 months (range 26-62 months). Bony union was confirmed at a mean of 3.7 months (range, 3-5 months) in all patients. Massive pulmonary embolism was seen in one patient. No cases of non-union, implant cutout or any other complications developed.

Conclusion: Post-polio patients are at high risk of fractures. Extramedullary internal fixation devices provide effective stability for bony union and good functional results in poliorelated femoral fractures.

\section{INTRODUCTION}

Acute poliomyelitis (polio) is a disease of the anterior horn motor neurons of the spinal cord and brain stem that arises from the poliovirus. Although it has been eradicated in developed countries, unfortunately, new cases are still reported in some developing or least developed countries. Survivors of acute poliomyelitis have common sequelae of lower extremity paralysis characterized by flaccid muscle tone, asymmetric involvement and retarded growth. ${ }^{[l]}$ Affected extremities may become more flaccid and weakened, resulting in limited ambulation and increased frequency of falling in the aging population. Because of these problems in the related extremity, the less functional extremity is less used by the patient. Because of that, such patients may be at risk of disuse osteoporosis, and after that, osteoporotic fractures. ${ }^{[2,3]}$
The treatment of fractures in polio-affected extremities continues to be a surgical dilemma. Because these unique fractures are not like the fractures, orthopedic surgeons deal with every day. Morbidity ranges from $35 \%$ to $48 \%$. ${ }^{[3,4]}$ Femoral fractures in elderly post-polio patients with osteopenia present a difficult management problem. There were some known factors that may contribute to poor fracture healing in polio-affected extremities; osteopenic, small, deformed and hypo-vascular bones (because of the impaired skeletal development). ${ }^{[5-7]}$ Decreased muscle strength and limited ambulation may cause challenging post-operative rehabilitation. ${ }^{[3]}$ Although the surgical outcomes of femoral fractures in the non-polio-affected patients are well known, there is not satisfying information about the results of surgical treatment in femoral fractures of post-polio patients. 
This study aims to assess and present the various fracture patterns and challenges faced in the fixation of these femoral fractures in polio-affected extremities. As this condition is such very few parts of everyday practice in orthopedics, orthopedic trauma surgeons should be aware of the management of these rare complex fracture patterns.

\section{MATERIALS AND METHODS}

A retrospective review was made of 16 consecutive postpolio patients who were treated for a unilateral closed femoral fracture between January 2015 and January 2017. A total of three patients were excluded from this study: one patient due to incomplete follow-up data, and two patients with a history of tibial fracture. The study was completed with 13 patients, comprising five males and eight females with a mean age of 62 years (range, 47-88 years). The fractures arose from falls during activities of daily living in 12 patients, and pedestrian accident in one patient. No open fracture was determined, and all fractures were classified according to the Association for Osteosynthesis/Orthopedic Trauma Association classification (AO/OTA) (Table I). All the fractures were located in the diaphysis and proximal region, and there were no cases of distal femoral fracture.

Surgery was performed at mean 5.4 days (range, 3-16 days) after injury; within a week in II patients, and on the $10^{\text {th }}$ and $16^{\text {th }}$ day after fracture in two patients because of co-morbidities. No patient had any fracture history in the polio-affected extremity. At the final follow-up examination, functional status was evaluated according to the Vignos Disability Scale, and this was compared with the status before fracture (Table 2). ${ }^{[8]}$
All surgical procedures were carried out by three different senior orthopedic trauma surgeons (HC, EE, SG). In 10 cases, the operations were performed with the patient in the supine position on a radiolucent operating table and for three patients, a traction table was used. A longitudinal, lateral femoral incision $(8-10 \mathrm{~cm})$ was made over the thigh that depends on devices. The subcutaneous tissues were incised in line with the skin incision to expose the femur. The reduction was achieved with a traction table in three patients and with manual traction in 10 patients. The flexion deformity of the knee and the reduced bulk of muscles were the reasons for failure to use the traction table. Then the extramedullary internal fixation devices used to final fixation. The mean duration of surgery was 68 minutes (range, 45-110 mins). Mean intraoperative blood loss was $100 \mathrm{~mL}$ (range, $50-500 \mathrm{~mL}$ ); no patients required any transfusion. All patients were treated with extramedullary internal fixation devices (locking plate in eight diaphyseal fractures; dynamic condylar screw (DCS) and plate in three, and dynamic hip screw (DHS) and plate in two proximal femoral fractures) (Fig. I). No bone grafts were needed.

Passive movement of the knee and hip joints was started on postoperative day two, followed by active exercises (straight leg raises and active knee-hip flexion) on day three. Gradual progression to pre-fracture weight-bearing was dependent on the progress of the radiological union. Venous thromboembolism prophylaxis with low molecular weight heparin was given to all patients.

Patients were regularly followed up at postoperative six weeks, three and six months, and one year. At each followup visit, antero-posterior (AP) and lateral radiographs of the femur were taken for the evaluation of callus formation and fracture union by the operating surgeon and an

Table I. Demographic and clinical characteristics of the patients

\begin{tabular}{|c|c|c|c|c|c|c|c|c|c|}
\hline & \multirow[t]{2}{*}{ Age } & \multirow[t]{2}{*}{ Sex } & \multirow{2}{*}{$\begin{array}{l}\text { Union time } \\
\text { (months) }\end{array}$} & \multirow{2}{*}{$\begin{array}{l}\text { Follow-up } \\
\text { (months) }\end{array}$} & \multirow[t]{2}{*}{ Diagnosis } & \multirow[t]{2}{*}{ Treatment } & \multirow{2}{*}{$\begin{array}{l}\text { AO } \\
\text { Class. }\end{array}$} & \multicolumn{2}{|c|}{ Vignos Grade } \\
\hline & & & & & & & & Pre-fracture & Post-fracture \\
\hline I & 50 & $\mathrm{~F}$ & 4 & 26 & Left femoral diaphyseal frc & Locking plate & $32 \mathrm{C} 2$ & 2 & 2 \\
\hline 2 & 49 & $\mathrm{~F}$ & 3 & 61 & Right subtrochanteric frc & Locking plate & 32B2 & 5 & 5 \\
\hline 3 & 52 & $\mathrm{~F}$ & 4 & 45 & Left femoral diaphyseal frc & Locking plate & 32B2 & 2 & 2 \\
\hline 4 & 47 & M & 3 & 51 & Right intertrochanteric frc & Locking plate & $3|A| 3$ & 3 & 3 \\
\hline 5 & 61 & $\mathrm{~F}$ & 3 & 48 & Right femoral diaphyseal frc & Locking plate & $32 \mathrm{Al}$ & 2 & 2 \\
\hline 6 & 60 & $\mathrm{~F}$ & 4 & 58 & Right femoral diaphyseal frc & Locking plate & $32 \mathrm{~A} 3$ & 3 & 3 \\
\hline 7 & 40 & $\mathrm{~F}$ & 3 & 38 & Left intertrochanteric frc & DCS & $31 \mathrm{~A} 22$ & 3 & 3 \\
\hline 8 & 85 & $\mathrm{~F}$ & 5 & 44 & Left subtrochanteric frc & Locking plate & $3 \mid \mathrm{A} 22$ & 2 & 2 \\
\hline 9 & 88 & M & 3 & 45 & Right intertrochanteric frc & DHS & $3|A| 3$ & 4 & 4 \\
\hline 10 & 83 & $\mathrm{~F}$ & 4 & 60 & Right intertrochanteric frc & DHS & $3|A| 3$ & 3 & 3 \\
\hline II & 70 & M & 3 & 52 & Left intertrochanteric frc & DCS & 3 IA33 & 4 & 4 \\
\hline 12 & 64 & M & 4 & 42 & Left femoral diaphyseal frc & Locking plate & $32 \mathrm{~A} 3$ & 2 & 2 \\
\hline 13 & 58 & M & 5 & 62 & Right intertrochanteric frc & DCS & $31 \mathrm{~A} 22$ & 2 & 2 \\
\hline Av. & 62.1 & & 3.7 & 48.6 & & & & 2.8 & 2.8 \\
\hline
\end{tabular}

M: Male; F: Female; DCS: Dynamic condylar screw; DHS: Dynamic hip screw; AO Class: Association for Osteosynthesis Classification; Av: Average. 
Table 2. Vignos Disability Scoring System for lower extremity ${ }^{[8]}$

\begin{tabular}{|c|c|}
\hline Grade & Functional description \\
\hline I & Walks and climbs stairs without assistance \\
\hline 2 & Walks and climbs stair with the aid of railing \\
\hline 3 & $\begin{array}{l}\text { Walks and climbs stairs slowly with the aid of } \\
\text { railing (over } 25 \text { seconds for eight standard steps) }\end{array}$ \\
\hline 4 & $\begin{array}{l}\text { Walks unassisted and rises from the chair but } \\
\text { cannot climb stairs }\end{array}$ \\
\hline 5 & $\begin{array}{l}\text { Walks unassisted but cannot rise from the chair or } \\
\text { climb stairs }\end{array}$ \\
\hline 6 & $\begin{array}{l}\text { Walks only with assistance or walks independently } \\
\text { with long leg braces }\end{array}$ \\
\hline 7 & $\begin{array}{l}\text { Walks in long leg braces but requires assistance for } \\
\text { balance }\end{array}$ \\
\hline 8 & $\begin{array}{l}\text { Stands in long leg braces but unable to walk even } \\
\text { with assistance }\end{array}$ \\
\hline 9 & In a wheelchair, elbow flexors more than antigravity \\
\hline 10 & $\begin{array}{l}\text { In a wheelchair or bed, elbow flexors less than } \\
\text { antigravity }\end{array}$ \\
\hline
\end{tabular}

independent observer (orthopedic surgeon). Bony union was defined as callus bridging being present in at least three out of four cortices on AP and lateral views.

\section{RESULTS}

Mean postoperative hospital stay was six days (range, 3-9 days). Callus bridging was first seen on the radiographs of $10(77 \%)$ patients in postoperative week six. Bony union was confirmed at a mean of 3.7 months (range, 3-5 months) in all patients. Massive pulmonary embolism was seen in one patient at postoperative three months because of deep venous thrombosis. Non-union, implant cutout or any other complication was not observed in any patient.

Ambulation started with axillary crutches at the post-operative second day. If there was no limb length discrepancy,

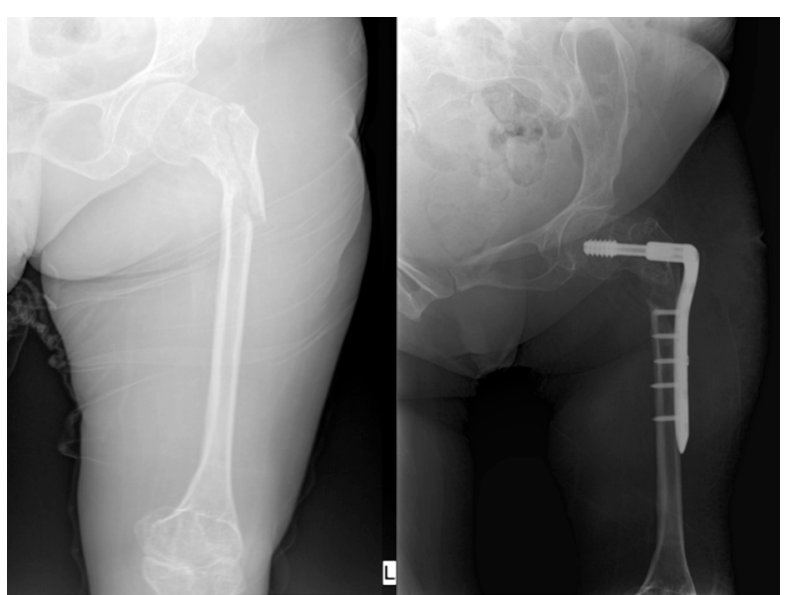

Figure 1. Patient number 7 . She had left intertrochanteric femoral fracture that treated with DCS the patients encouraged to contact with the fingertip for balance from the post-operative second day until the sixth weeks. Then patients were continued slowly increasing the weight as much as can tolerate after post-operative sixth weeks. Gradually abandonment of the use of assistive devices was recommended. The home rehabilitation program was administered to all patients, in view of the difficulty of accessibility and lack of transportation. All patients returned to the same pre-fracture Vignos grade of disability and ranges of motion of the related joint at the final follow-up examination.

\section{DISCUSSION}

There are a limited number of studies in the literature about the surgical management of femoral fractures of polio-affected extremities. The management of femoral fracture of polio-affected extremities can show that good results with extramedullary internal fixation devices instead of intramedullary internal fixation devices.

In this study, fixation of proximal and diaphyseal femoral fractures in polio-affected extremities with standard DHS, DCS or locked plates was found to have a high bone union rate without any reported complication, such as nonunion, malunion or infection.

Because of the rarity of the disease, the management of rare femoral fractures of polio-affected extremity in the adults poses a problem. Early fixation and mobilization, which is one of the main goals of orthopedic treatment, are also important for these patients. Previous studies reported that prolonged cast immobilization may worsen osteopenia and joint contracture, and may also bring about associated complications, such as bed sores and non-union. ${ }^{[9]}$ Mohammad et al. ${ }^{[10]}$ reported that their outpatient post-polio patients had osteopenia or osteoporosis in $96 \%$, and $38 \%$ of their patients had experienced a fracture at a 5-year follow-up. Another study about polio survivors reported that $61 \%$ of 233 community-based participants had falls for which they needed medical care, including $35 \%$ who had sustained a fracture. ${ }^{[4]}$

Most post-polio patients have small and deformed bones on the affected side. This problem affects and determines the surgeon's choice of treatment. Implants used for femoral fractures under normal conditions may not be suitable for fractures in polio-affected extremities due to the aforementioned drawbacks. In a study of 16 postpolio patients, a locked compression plate was applied to distal femur fractures. ${ }^{\left[{ }^{11}\right]}$ Locked compression plates are one of the gold standard treatment modalities in distal femoral fractures. ${ }^{[2]}$ However, anatomic locking plates or intramedullary nailing may not be appropriate for postpolio fractures, so custom-made implants or implants for different anatomic regions are recommended for postpolio femoral fractures. ${ }^{[13]}$ Extramedullary fixation devices can be used instead of using intramedullary fixation devices or custom-made fixation devices in these unusual fractures. 
A polio-affected extremity is a risk factor for disuse osteoporosis. ${ }^{[10]}$ The prevalence of osteopenia and osteoporosis is much higher in polio-affected extremities compared to the general population. ${ }^{[14]}$ Quadriceps muscle strength and regular exercise have been shown to be important predictive factors associated with disuse osteoporosis. ${ }^{[6]}$ Due to the increased risk of regional osteoporosis in post-polio syndrome, regional osteoporosis must be checked and if the patient has osteoporosis, this should be treated accordingly as there is clearly higher risk of fracture.

The Vignos disability scale can be used in the evaluation of post-polio survivors. In a study of 13 femoral fractures of polio-affected extremities, callus formation and Vignos grade were seen to be statistically significantly correlated. ${ }^{[15]}$ In the current study, all patients returned to the same pre-fracture Vignos grade of disability at the final follow-up examination.

The proximal femoral nail is the current recommended fixation device for fixing the most extracapsular hip fractures. [16] The main problem found on treating proximal femoral fractures in polio-affected extremities was the presence of narrow intramedullary canal, which prevented the use of a proximal femoral nail. The extramedullary internal fixation devices were used to resolve this problem. Khalil A. said that the use of locking compression plates in femoral fractures of polio-affected extremities are beneficial, because of they may be contoured to the non-anatomic shape of the bone and are indicated in osteoporotic/disused bone. ${ }^{[15]}$

$A O$ surgery reference recommends $P F N$ and DHS for most intertrochanteric fractures, and intramedullary nailing for most femoral diaphyseal fractures. However, the recommendations are not valid for most polio-affected femoral fractures. In this study, the surgical fixation method and implant choice for these different fracture patterns were found to conflict with AO surgery principles. Although intramedullary fixation is the gold standard treatment for proximal and diaphyseal femoral fractures with normal anatomy, extramedullary fixation was selected for all patients because of the deformed anatomy of the postpolio femur (narrow intramedullary canal; increased bowing; decreased neck-shaft angle). It is difficult to manage these unusual fracture patterns with a common fracture management protocol, and decisions must be made on an individual patient basis.

Limitations of the present study include the small sample size, non-homogeneous implants, the retrospective nature of this study, and the absence of a control group.

In conclusion, fractures in a polio-affected extremity are not a common entity and are difficult to manage with a standard fracture management protocol. Extramedullary fixation methods were seen to be suitable for proximal and diaphyseal fractures in post-polio patients, considering the challenges of a small, deformed, osteoporotic and hypo-vascularized femur.

Ethics Committee Approval

Approved by the Kartal Dr. Lütfi Kırdar Training and Re- search Hospital Local Ethics Committee (2019/5/4//47/7). Date: 13/02/2019.

Informed Consent

Retrospective study.

Peer-review

\section{Internally peer-reviewed.}

Authorship Contributions

Concept: H.B.Ç., S.A.G.; Design: H.B.Ç., E.E.; Supervision: S.A.G.; Materials: H.B.Ç., E.E., S.A.G.; Data: H.B.Ç., S.E.; Analysis: H.B.Ç., S.E.; Literature search: H.B.Ç., S.E.; Writing: H.B.Ç., S.E.; Critical revision: H.B.Ç., E.E., S.A.G., S.E.

Conflict of Interest

None declared.

\section{REFERENCES}

1. Gawne AC, Halstead LS. Pathophysiology and Clinical Management on Post-Polio Syndrome. Critical Reviews ${ }^{\mathrm{Tt}}$ in Physical and Rehabilitation Medicine 2017;29:1-4. [CrossRef]

2. Prince RL, Price RI, Ho S. Forearm bone loss in hemiplegia: a model for the study of immobilization osteoporosis. J Bone Miner Res 1988;3:305-10. [CrossRef]

3. Goerss JB, Atkinson EJ, Windebank AJ, O'FALLON WM, MELTON III LJ. Fractures in an aging population of poliomyelitis survivors: a community-based study in Olmsted County, Minnesota. Mayo Clinic Proceedings 1994;69:333-9. [CrossRef]

4. Silver JK, Aiello DD. Polio survivors: falls and subsequent injuries. Am J Phys Med Rehabil 2002;81:567-70. [CrossRef]

5. Sharrard WJ. Paralytic deformities of the lower limb. Int Orthop 1984;8:147-54. [CrossRef]

6. Chang KH, Lai CH, Chen SC, Tang IN, Hsiao WT, Liou TH, et al. Femoral neck bone mineral density in ambulatory men with poliomyelitis. Osteoporos Int 2011;22:195-200. [CrossRef]

7. Lloyd ME, Spector TD, Howard R. Osteoporosis in neurological disorders. J Neurol Neurosurg Psychiatry 2000;68:543-7. [CrossRef]

8. Vignos PJ Jr, Archibald KC. Maintenance of ambulation in childhood muscular dystrophy. J Chronic Dis 1960;12:273-90. [CrossRef]

9. Versluysen M. How elderly patients with femoral fracture develop pressure sores in hospital. Br Med J (Clin Res Ed) 1986;292:1311-3.

10. Mohammad AF, Khan KA, Galvin L, Hardiman O, O'Connell PG. High incidence of osteoporosis and fractures in an aging post-polio population. Eur Neurol 2009;62:369-74. [CrossRef]

11. Wang WJ, Shi HF, Chen DY, Chen YX, Wang JF, Wang SF, et al. Distal Femoral Fractures in Post-poliomyelitis Patients Treated with Locking Compression Plates. Orthop Surg 2013;5:118-23. [CrossRef]

12. Xing W, Lin W, Dai J, Kong Z, Wang Y, Sun L, et al. Clinical effect of locking compression plate via posterolateral approach in the treatment of distal femoral fractures: a new approach. J Orthop Surg Res 2018;13:57. [CrossRef]

13. Kumar TS, Senthilnathan A, Prabhakar R. Choice of implants in management of fractures in patients with post-polio residual paralysis. Int J Orthod Sci 2017;3:577-83. [CrossRef]

14. Bickerstaffe A, Beelen A, Nollet F. Circumstances and consequences of falls in polio survivors. J Rehabil Med 2010;42:908-15. [CrossRef]

15. El-Sayed Khalil A. Locked plating for femoral fractures in polio patients. Arch Orthop Trauma Surg 2010;130:1299-304. [CrossRef]

16. Arirachakaran A, Amphansap T, Thanindratarn P, Piyapittayanun P, Srisawat P, Kongtharvonskul J. Comparative outcome of PFNA, Gamma nails, PCCP, Medoff plate, LISS and dynamic hip screws for fixation in elderly trochanteric fractures: a systematic review and network meta-analysis of randomized controlled trials. Eur J Orthop Surg Traumatol 2017;27:937-52. [CrossRef] 


\section{Yaşlanan Erişkin Polio Popülasyonunda Femur Kırıklarının Tedavisi: 13 Olgunun Geriye Dönük Değerlendirilmesi}

Amaç: Polio geçiren hastalarda azalmış kas tonusu, sınırlı ambulasyon, asimetrik tutulum, gecikmiş büyüme ve kullanmama osteoporozu ile karakterize alt ekstremite paralizisinin genel sekelleri vardır. Kullanmama osteoporozu riski taşıyan bu hastalar aynı zamanda osteoporotik kırık geçirme riski altındadırlar. Bu çalışmanın amacı, ekstramedüller internal fiksasyon cihazlarının polio ilişkili osteoporotik femoral kırıklarda daha iyi sonuçlar elde etmedeki etkinliğini değerlendirmektir.

Gereç ve Yöntem: Toplam 13 yetişkin polio hastası geriye dönük olarak değerlendirildi. Tek taraflı proksimal ve diyafizer femur kırığı için ekstra medüller internal fiksasyon cihazları ile tedavi edildi. Tüm hastaların fonksiyonel durumları Vignos sakatlık derecesi ile değerlendirildi.

Bulgular: Tüm hastalar (ort. yaş 62; dağıım 47-88) ekstra-medüller iç fiksasyon cihazları ile tedavi edildi. Sekiz diyafizer kırığa kilitli plak uygulandı. Proksimal femur kırıklarının üçü kayan kondil vidası ile ve ikisi kayan kalça vidası ile tedavi edildi. Ortalama takip süresi 48.6 aydı (dağılım 26-62 ay). Kemik kaynama süresi tüm hastalarda ortalama 3.7 ayda (dağılım, 3-5 ay) tespit edildi. Bir hastada masif pulmoner emboli görüldü. Kaynamama, materyal yetmezliği veya başka herhangi bir komplikasyon görülmedi.

Sonuç: Polio geçirmiş olan hastalar yüksek kırık riski taşır. Ekstra medüller internal fiksasyon cihazları, polio ile ilişkili femur kırıkları için uygun stabiliteyi ve iyi fonksiyonel sonuçları sağlar.

Anahtar Sözcükler: Femur kırı̆̆ı; kullanmama osteoporozu; polio. 